\title{
A CASE OF VERTEBRAL COALESCENCE IN LUCIOBARBUS XANTHOPTERUS (HECKEL, 1843) (PISCES: CYPRINIDAE) OBTAINED FROM THE LOWER REACHES OF MESOPOTAMIA
}

\author{
LAITH A. JAWAD, ABBAS J. AL-FAISAL, MUSTAFA AL-MUKHTAR
}

\begin{abstract}
A severe coalescence involving 11 thoracic and 11 caudal vertebrae was noticed in the posterior part of the thoracic and anterior part of the caudal regions of the vertebral column of the abnormal specimen of Luciobarbus xanthopterus collected from Al-Huwaza Marsh, Maisan Province, South of Iraq. Also, other minor anomalies were noticed in the specimen in question. Probably, genetic and epigenetic causes may be implicated in this anomaly.

Résumé. Une fusion sévère impliquant 11 vertèbres thoraciques et 11 vertèbres caudales a été remarquée dans la partie postérieure de la région thoracique et la partie antérieure de la région caudale de la colonne vertébrale d'un spécimen anormal de Luciobarbus xanthopterus collecté par Al-Huwaza Marsh en Province Maisan, Sud de l'Irak. En outre, d'autres anomalies mineures ont été constatées sur l'échantillon en question. Probablement, des causes génétiques et épigénétiques pourraient être impliquées dans cette anomalie.
\end{abstract}

Key words: abnormality, vertebral coalescence, Luciobarbus xanthopterus, Iraq.

\section{INTRODUCTION}

Skeletal anomalies are a fundamental problem in fish development, and can reduce their survival. Skeletal abnormalities occur in wild fish populations, but are fairly rare (Al-Hassan, 1983; Ferreri et al., 2000; Sanger \& McCune, 2002; Gavaia et al., 2002, 2009; Jawad \& Al-Mamary, 2012; Jawad, 2013; Jawad et al., 2013). Abnormalities in fishes, whether caused by external or internal factors are either so severe that they affect their fitness, or slight and do not affect their survival.

Vertebral column abnormalities have been reported for different fish species worldwide (Haaker, 1977; Galván-Magaňa et al., 1994). The types of abnormal vertebral development include lordosis (dorso-ventral curvature), scoliosis (lateral spinal curvature) (Haaker, 1977), fusion of neighbouring vertebrae, and hyperostosis, among others.

The rate of occurrence and pattern of skeletal anomalies is commonly used to monitor the consequences of environmental stresses caused by human (Boglione et al., 2001; Ershov, 2008). In larval and juvenile stages, the external factors mainly have effect, regularly targeting skeletal development (Pavlov, 1997; Haaparanta et al., 1997). Such factors can be the presence of pollutants and mutagens (Lindesjoo et al., 1994). The malformation processes occur in the early stages of development and their causes are not always well known (Koumoundouros et al., 1997). The factors that can cause these abnormalities range from diseases, parasites, e.g., trematodes (Kelly et al., 2010), lack of essential elements, malnutrition, to toxic algal blooms (Heupel et al., 1999) and water temperature. These are some of the most important environmental factors influencing the appearance of early morphological abnormalities during early development of fish (Laurel \& Blood, 2011). Environmental factors may be quite complex, involving mutations which disrupt embryogenesis (Yamauchi et 
al., 2006), as in the case for radiation, considered one of the major anthropogenic environmental stresses (Bogutskaya et al., 2011).

No malformations have been recorded in the cyprinid Luciobarbus xanthopterus. This species is characterized by two pairs of barbels, a serrated dorsal fin spine, small scales, and subterminal to terminal oblique mouth. The body is without distinctive marks, with brownish to bluish grey back (Coad, 2010). This species is distributed in the Tigris-Euphrates basin. In Iraq, it is found in Shatt Al-Arab River and its tributaries, in Tigris and Euphrates Rivers and their tributaries (Coad, 2010). It is a commercially important species and it is usually on high demand in fish markets in Iraq, Iran, Turkey and Syria. One kilogramme of this fish can cost more than U.S. $\$ 10$ in the Middle East countries.

Coalescence of vertebrae is an abnormality that has been reported to occur in several fish groups, both in farmed and wild populations (Divananch et al., 1996); extensive fusion of vertebrae can affect the shape of the body (Boglione et al., 1993).

In the present study, we describe a skeletal abnormality in an adult fish specimen of Luciobarbus xanthopterus. There are no previous reports on skeletal anomalies in this species from Iraqi waters. Thus, the abnormal case reported here is considered the first record to the Iraq freshwater fish fauna. The objective of work is to contribute to the identification of specific anatomical descriptions useful to set up morphological quality criteria.

\section{MATERIAL AND METHODS}

Adult specimen of Luciobarbus xanthopterus with skeletal deformity described in this study was obtained on the $3^{\text {rd }}$ of March 2009 from Al-Huwaza Marsh, Maisan

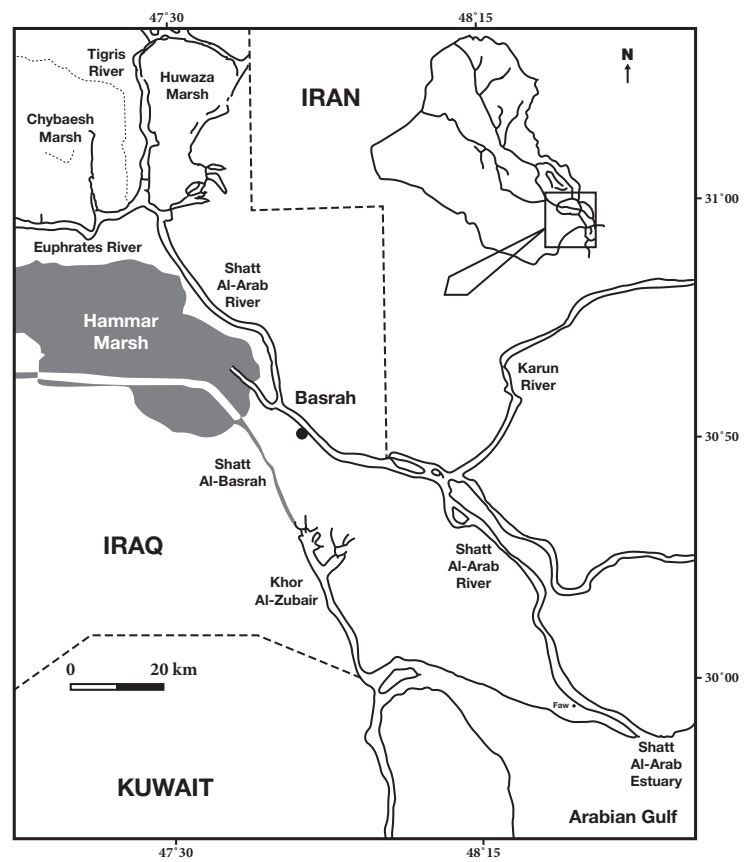

Fig. 1 - Map showing the collection site 


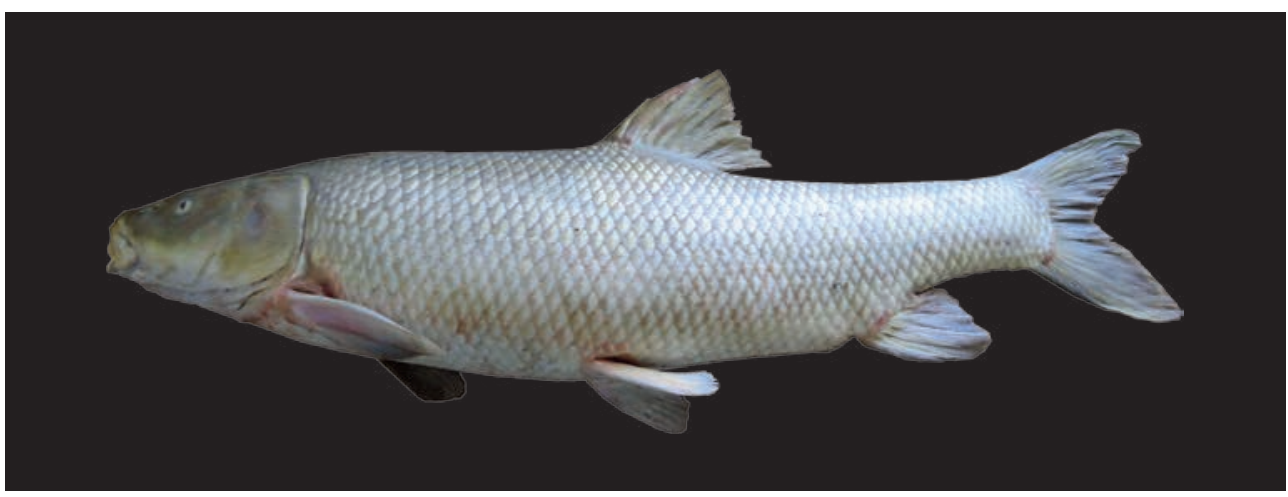

Fig. 2 - Luciobarbus xanthopterus, $585 \mathrm{~mm}$ total length, normal

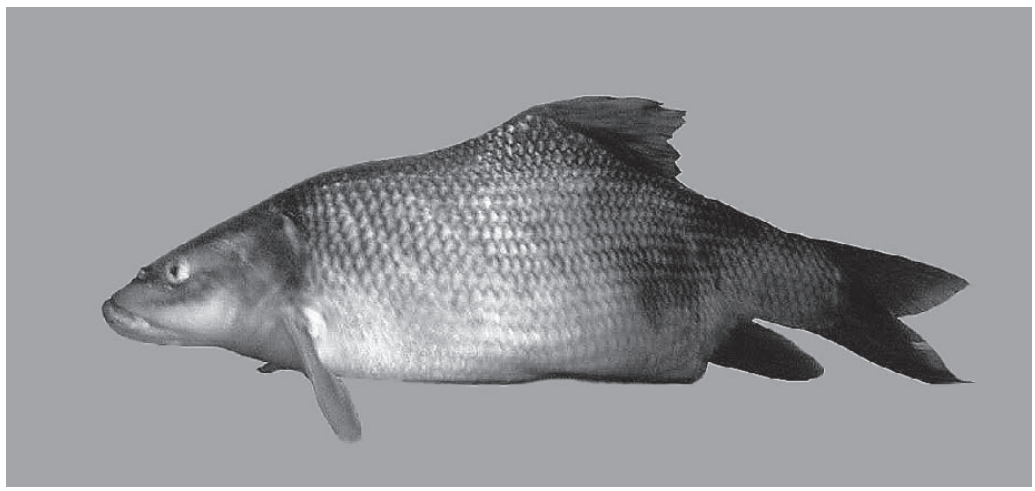

Fig. 3 - Luciobarbus xanthopterus, $598 \mathrm{~mm}$ total length, abnormal

Province, $350 \mathrm{~km}$ south of Baghdad City Capital (31 '23'35.72” N, 47³8'33.04”' E) (Fig. 1). Both normal specimen (Fig. 2) used for comparison and the abnormal fish (Fig. 3) came from the same area. The skeletons of both normal and abnormal specimens were prepared by boiling the fish (Fig. 4). The length of the vertebral column from the anterior margin of the first vertebra to the posterior margin of the last vertebra is divided by fish total length to produce a ratio that is used to compare abnormal fish with normal fish. Measurements for the deformed specimen are as follows: total length $585 \mathrm{~mm}$, standard length $574 \mathrm{~mm}$, fork length $420 \mathrm{~mm}$, head length $180 \mathrm{~mm}$, body depth $220 \mathrm{~mm}$. The vertebral column of the normal and abnormal specimens were deposited in the ichthyological collection of the Marine Science Centre, University of Basrah, Iraq.

\section{RESULTS}

The vertebral column of the deformed specimen of L.xanthopterus is composed of 20 thoracic and 19 caudal vertebrae. This number is similar to the normal specimen. A severe coalescence involving 11 thoracic and 11 caudal vertebrae was noticed in the posterior part of the thoracic and anterior part of the caudal regions of the vertebral column of the abnormal specimen (Fig. 4, below). Except for the $9^{\text {th }}$ caudal vertebrae, the remaining fused thoracic and caudal vertebrae involved in the 


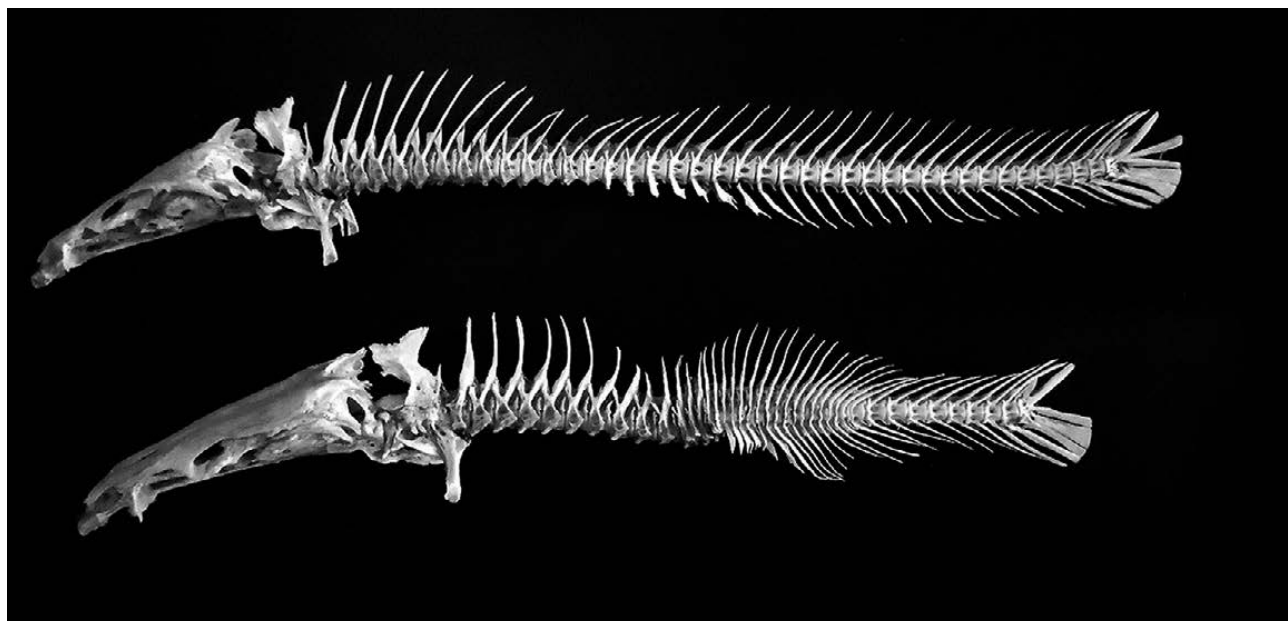

Fig. 4 - Vertebral column of Luciobarbus xanthopterus, normal above, abnormal below.

coalescence have completely lost their normal shape and were transformed into an irregular lump of bony material where only the neural and haemal spines are left. The $9^{\text {th }}$ caudal vertebra is severely reduced, so that only the neural and haemal spines are left. The $15^{\text {th }}$ vertebra appeared to have its neural spine divided in two, with its centrum significantly reduced. Instead of being directed backwards as in the normal specimen, the analysed specimen presented: neural spines of ten abnormal thoracic vertebrae directed upwards, neural spine of the $11^{\text {th }}$ slightly directed backwards, neural spines from the $1^{\text {st }}$ to the $5^{\text {th }}$ caudal vertebrae slightly directed backwards and the neural spines of the $6^{\text {th }}$ to $11^{\text {th }}$ bent further back and down. The neural spines of all the involved vertebrae in this coalescence are wavy and curved at the tip, especially those of the $6^{\text {th }}$ and $7^{\text {th }}$ caudal vertebrae. The parapophysis of the $12^{\text {th }}$ and $14^{\text {th }}$ thoracic vertebrae are deformed and extended downwards, looking like short haemal spines. As for the vertebra no. 13, it is completely absent and the neural spine and its base only are what is left of it. The haemal spines of the $1^{\text {st }}$ to the $5^{\text {th }}$ caudal involved vertebrae are wavy and more downwards directed than backwards, as in the normal specimen. Those of the $6^{\text {th }}$ and $7^{\text {th }}$ are shorter than the rest of the haemal spines and those of the $8^{\text {th }}$ to the $11^{\text {th }}$ vertebrae are irregularly directed backwards and downwards. The neural spines of the $1^{\text {st }}$ to the $10^{\text {th }}$ vertebrae are directed upwards instead of backwards as in the normal specimen.

The coalescence of vertebrae in L. xanthopterus had an obvious effect on body length. Normal L. xanthopterus had a vertebral column length / total fish length ratio of 0.51 , while a ratio of 0.36 is obtained for fish specimen with coalescent vertebrae. Externally, the deformed fish specimen appeared to have big hump at the base of the dorsal fin. This hump lies exactly above the area of the coalescent vertebrae.

\section{DISCUSSION}

The cases of malformed vertebral columns represent $13 \%$ of the described deformity worldwide (Galván-Magaňa et al., 1994). Unfavourable conditions during embryonic development, e.g., unfavourable temperature and low oxygen levels, malnutrition, genetic causes and pollution, stress as an agent of abnormalities can 
attribute to the high incidence of vertebral anomalies in fishes (Divananch et al., 1996). Skeletal abnormalities generally initiate in the early developmental stages, thus this fish might have been living for several years with its abnormalities (Haaker, 1977) and this kind of malformation would not have interfered with its biological activities, such as feeding (Ribeiro-Prado et al., 2008). Only in some cases, fishes with deformed vertebrae can develop an abnormal style of locomotion, with loss of forward speed and a characteristic use of one of the pectoral fins to equilibrate posture (Ribeiro-Prado et al., 2008). The deformation in L. xanthopterus was not fatal, but we do not know if it affected the mobility in some way. All the fins were found in apparently perfect condition. It is difficult to determine the cause of this abnormality; multiple causes can be suggested (genetic, climatic conditions, malnutrition, parasites, pollution, etc.), however, further studies and monitoring are necessary to elucidate the occurrence of this phenomenon. Due to the abnormality in the middle part of vertebral column, the fish did not reach full size, and appeared shorter than normal, with a hump at the base of the dorsal fin. In spite of this, this cyprinid fish maintained a nearly normal body form.

\section{ACKNOWLEDGEMENTS}

Our sincere thanks are due to the Marine Science Centre, University of Basrah, Iraq for giving us the opportunity to work on the fish specimens of the marsh area and for providing all the needs for accomplish this study. Our thanks should also go to Daniel Pauly, Fisheries Centre, University of British Columbia, Canada for reading and editing the manuscript and for his valuable advice and suggestions.

\section{UN CAZ DE FUZIUNE VERTEBRALĂ LA LUCIOBARBUS XANTHOPTERUS (HECKEL, 1843) (PISCES: CYPRINIDAE) COLECTAT DIN ZONA INFERIOARA A MESOPOTAMIEI}

\section{REZUMAT}

O fuziune gravă care implică 11 vertebre toracice și 11 caudale a fost observată în partea posterioară a zonei toracice și a zonei anterioare a regiunii caudale a coloanei vertebrale a exemplarului de Luciobarbus xanthopterus colectat de la Al-Huwaza Marsh, din provincia Maisan, la sud de Irak. De asemenea, alte anomalii minore au fost găsite în acest exemplar. Cel mai probabil, cauze genetice și epigenetice sunt implicate în această anomalie.

\section{LITERATURE CITED}

AL-HASSAN, L. A. J., 1983 - Vertebral abonomalities in Mesopotamichthys sharpeyi and Carasobarbus luteus (Pisces: Cyprinidae) from Basrah, Iraq.Cybium, 7: 7-10.

BOGUTSKAYA, N. G., M. A. ZUYKOV, A. M. NASEKA, B. ANDERSON, 2011 - Normal axial skeleton structure in common roach Rutilus rutilus (Actinopterygii: Cyprinidae) and malformations due to radiation contamination in the area of the Mayak (Chelyabinsk Province, Russia) nuclear plant. Journal of Fish Biology, 79: 991-1016.

BOGLIONE, C., G. MARINO, B. BERTOLINI, A. ROSSI, F. FERRERI, S. CATAUDELLA, 1993 - Larval and post larval monitoring in sea bass: morphological approach to evaluate finfish seed quality. In: G. Barnabe, P. Kestmont (eds.), Aquaculture 92. Production, Environment and Quality. European Aquaculture Society, Special Publication 18: 189-204.

BOGLIONE, C., F. GAGLIARDI, M. SCARDI, S. CATAUDELLA, 2001 - Skeletal descriptors and quality assessment in larvae and post-larvae of wild-caught and hatchery-reared gilthead sea bream (Sparus aurata L., 1758). Aquaculture, 192: 1-22.

COAD, B., 2010 - Freshwater fishes of Iraq. Pensoft Series Faunistica, Pensoft Publishers, Moscow 93: $1-274$.

DivANACH, P., C. BOGLIONE, B. MENU, G. KOUMOUdOUROS, M. KENTOURIM, S. CATAUDELLA, 1996 - Abnormalities in finfish mariculture: an overview of the problem, causes and solutions. In: B. CHANTAIN, M. SAROGLIA, J. SWEETMAN, P. LAVENS (eds.), Seabass and seabream culture: Problem and prospects. International Workshop. Verona, Italy. October 16-18, 1996. European Aquacultural Society, Oostende, Belgium. 
ERSHOV, P. N., 2008 - The vertebral abnormalities in eelpout Zoarces viviparus (Linnaeus, 1758) (Pisces, Zoarcidae). Proceedings of the Zoological Institute, RAS, 312: 74-82.

FERRERI, F., C. NICOLAIS, B. BOGLIONE B, B. BERTOLINI, 2000 - Skeletal characterization of wild and reared zebrafish: anomalies and meristic characters. Journal of Fish Biology, 56: 1115-1128.

GALVÁN-MAGAṄA, F., A. RODRÍGUEZ-ROMEROJ, L. A. ABITIA-CÁRDENAS, 1994 - First record of abnormal vertebral column in the green bar snapper Hoplopagrus guentheri (Osteichthyes: Lutjanidae). Revista de Biología Tropical, 14: 388-389.

GAVAIA, P. J., M. T. DINIS, M. L. CANCELA, 2002 - Osteological development and abnormalities of the vertebral column and caudal skeleton in larval and juvenile stages of hatchery-reared Senegal sole (Solea senegalensis). Aquaculture, 211: 305-323.

GAVAIA, P. J., S. DOMINGUES, S. EENROLA, P. DRAKE, C. SARASQUETE, M. T. DINIS, M. L. CANCELA, 2009 - Comparing skeletal development of wild and hatchery-reared Senegalese sole (Solea senegalensis Kaup, 1858): evaluation in larval and postlarval stages. Aquaculture Research, 40: 1585-1593.

HAAKER, P. L., 1977 - Abnormal vertebral development in northern anchovy, Engraulis mordax Girard. California Fish and Game, 3: 18-185.

HAAPARANTA, A., E. T. VALTONEN, R. W. HOFFMANN, 1997 - Gill anomalies of perch and roach from four lakes differing in water quality. Journal of Fish Biology, 50: 575-591.

HEUPEL, M. R., C. A. SIMPFENDORFER, M. B. BENNET, 1999 - Skeletal deformities in elasmobranch from Australian water. Journal of Fish Biology, 54: 1111-1115.

JAWAD, L., Z. SADIGHZADEH, A. SALARPOURI, S. AGHOUZBENI, 2013 - Anal Fin Deformity in the Longfin Trevally, Carangoides armatus. Korean Journal of Ichthyology, 25: 169-172.

JAWAD, L. A., 2013 - Hyperostosis in Three Fish Species Collected from the Sea of Oman. Anatomical Records, 296: 1145-1147.

JAWAD, L. A., J. M. AL-MAMRY, 2012 - Saddleback syndrome in wild silver promfret, Pampus argenteus (Euphrasen, 1788) (Family: Stromateidae) from the Arabian Gulf coasts of Oman. Croatian Journal of Fisheries, 3: 51-58.

KELLY, D., H. THOMAS, D. W. THIELTGES, R. POULIN, D. M. TOMPKINS, 2010 - Trematode infection causes malformations and population effects in a declining New Zealand fish. Journal of Animal Ecology, 79: 445-452.

KOUMOUNDOUROS, G., F. GAGLIARDI, P. DIVANACH, C. BOGLIONE, S. CATAUDELLA, M. KENTOURI, 1997 - Normal and abnormal osteological development of caudal fin in Sparus aurata L. fry. Aquaculture, 149: 215-226.

LAUREL, B. J., D. M. BLOOD, 2011 - The effects of temperature on hatching and survival of northern rock sole larvae (Lepidopsetta polyxystra). Fishery Bulletin, 109: 282-291.

LINDESJOO, E., J. THULIN, B. E. BENGTSSON, U. TJARMLUND, 1994 - Abnormalities of a gill cover bone, the operculum, in perch Perca fluviatilis from a pulp mill effluent area. Aquatic Toxicology, 28: 189-207.

PAVLOV, D. A., 1997 - Development of head skeleton and paired fin girdles in wolfish, Anarhichas lupus, at different temperature regimes. Journal of Ichthyology, 37: 294-303.

RIBEIRO-PRADO, C. C., M. C. ODDONE, M. M. BUENO-GONZÁLEZ, A. FERREIRA-DE AMORIM, C. CAPPAÉ, 2008 - Morphological abnormalities. Archives de Ciencias do mar, Fortaleza, 41: 21-28.

SANGER, T. J., A. R. McCUNE, 2002 - Comparative osteology of the Danio (Cyprinidae: Ostariophysi) axial skeleton with comments on Danio relationships based on molecules and morphology. Zoological Journal of the Linnaean Society, 135: 529-546.

YAMAUCHI, M., E.-Y. KIM, H. IWATA, Y. SHIMA, S. TANABE, 2006 - Toxic effects of 2, 3, 7, 8 - tetrachlorodibenzo-pdioxin (TCDD) in developing red seabream (Pagrus major) embryo: an association of morphological deformities with AHR1, AHR2 and CYP1A expressions. Aquatic Toxicology, 80: 166-179.

Received: January 9, 2015

Accepted: March 23, 2015
Laith A. Jawad

Manukau, Auckland, Newe Zealand

e-mail: laith_jawad@hotmail.com

Abbas J. Al-Faisal, Mustafa Al-Mukhtar

Marine Science Centre, University

of Basra, Basra - Iraq

e-mails: abbasjsm71@yahoo.com

mustafaalmukhtar1@gmail.com 